\title{
Pelaksanaan dan Pengembangan Sumber Daya Tenaga Kependidikan (Studi pada Madrasah Ibtidaiyah di Kabupaten Kerinci)
}

\author{
Egi Febrizon \\ Madrasah Ibtidaiyah Negeri 4 Kerinci \\ Email: efebrizon@gmail.com
}

\begin{abstract}
This study is intended to describe the implementation and development of the resources of educators in Madrasah Ibtidaiyah in Kerinci, including developing the competence of educators and improve the competence of personnel an educational institution. This is the study of the conceptual article. Data were collected using a literature review and documentation. The results of this study show: 1) competence development pattern of produce educators. The pattern of development of the competence of produce educators in Madrasah Ibtidaiyah in Kerinci general competencies, such as functional competencies, and other things the optimal, is enough is given to educational personnel such as education and training, workshops, training, functional training, structural position, and the development competence of IT. competency development Strategy 2) product educators in Madrasah Ibtidaiyah in Kerinci, such training is enough to power is given to a local optimum. 3) competency factors influencing the development of produce educators at the Madrasah Ibtidaiyah in Kerinci, i.e. internal factors such as: vision, mission, objectives, strategy of achievement of the objectives, nature and type of activities, and the type of technology used, as well as external factors such as government policies, the sociocultural society, and the development of science and technology.
\end{abstract}

Keywords: Development, Competence, Administration Personnel

\section{PENDAHULUAN}

Manusia dalam proses pendidikan adalah suatu hal yang paling utama. Sejarah membuktikan pada kita bahwa pendidikan dalam budaya masyarakat di mana pun berkepentingan mengarahkan manusia kepada tujuan-tujuan tertentu (Munirah, 2015). Di sisi lain, permasalahan pendidikan nasional yang muncul dan sedang dihadapi oleh bangsa Indonesia saat ini adalah rendahnya sumber daya manusia (SDM) baik tenaga pendidik maupun tenaga kependidikan pada setiap jenjang (Widodo, 2015). Di samping itu, berbagai usaha telah dilakukan dalam meningkatkan sumber daya manusia (SDM), antara lain melalui berbagai jenis pelatihan dan peningkatan kompetensi pendidik maupun tenaga kependidikan, perbaikan sarana dan prasarana, serta peningkatan mutu manajemen sekolah (Hadiyanto, 2004).

Pengelolaan sesuatu organisasi ditentukan oleh pengelolaan sumber daya manusia (Zaini, 2016). Untuk mendukung terwujudnya proses sumber daya manusia yang berkualitas berbagai suprastruktur dan infrastruktur perlu disiapkan untuk mewujudkan proses tersebut. Hasibuan 
(2006) menyatakan manajemen sumber daya manusia dapat diartikan sebagai ilmu mengatur hubungan dan peran tenaga kerja secara efektif dan efisien serta merupakan bagian dari manajemen umumnya yang memfokuskan diri pada unsur sumber daya manusia sehingga tercapai tujuan organisasi.

Peranan manajemen sumber daya manusia (MSDM) sangat menentukan bagi terwujudnya tujuan organisasi (Almasri, 2016). Manajemen sumber daya manusia merupakan suatu pengakuan terhadap pentingnya sumber daya manusia atau tenaga kerja dalam organisasi dan pemanfaatannya dalam berbagai fungsi serta kegiatan untuk mencapai tujuan organisasi. Sedarmayanti (2009) menyatakan manajemen sumber daya manusia adalah seni untuk merencanakan mengorganisasikan, mengarahkan, mengawasi kegiatan sumber daya manusia atau pegawai, dalam rangka mencapai tujuan organisasi.

Dapat disimpulkan bahwa manajemen sumber daya manusia merupakan suatu proses yang terdiri dari rekruitmen atau penarikan sumber daya manusia, seleksi, pengembangan SDM, pemeliharaan sumber daya manusia, dan penggunaan sumber daya manusia.

Pentingnya kompetensi aparat dalam suatu organisasi, pada dasarnya terkait masalah sumber daya manusia dalam kehidupan organisasi. Pada dasarnya ada beberapa jenis kompetensi yang harus dimiliki oleh pegawai. Azmy (2015) mengemukakan jenis-jenis kompetensi yang wajib dimiliki oleh pegawai, yaitu kompetensi umum, kompetensi fungsional, dan kompetensi manajerial. Strategi yang dapat dilakukan untuk mengembangkan kompetensi karyawan adalah dengan memberikan pengembangan kompetensi kepada karyawan agar karyawan tersebut dapat memiliki produktivitas dalam bekerja, pengembangan kompetensi dapat dilakukan dengan pendidikan, pelatihan, dan mentoring kepada karyawan agar dapat melaksanakan tugasnya dengan efektif dan efisien. Pengembangan kompetensi merupakan usaha untuk meningkatkan kemampuan teknis, teoritis, konseptual, moral, pegawai sesuai dengan kebutuhan jabatan.

Undang-undang Nomor 20 Tahun 2003

tentang Sistem Pendidikan Nasional menjelaskan tugas tenaga kependidikan yaitu tenaga kependidikan bertugas melaksanakan administrasi, pengelolaan, pengembangan, pengawasan, dan/atau memberikan pelayanan teknis untuk menunjang proses pendidikan pada satuan pendidikan (Presiden Republik Indonesia, 2003).

PP Nomor 19 tahun 2005 pasal 36 tentang standar pendidikan dan tenaga kependidikan yaitu tenaga kependidikan pada perguruan tinggi harus memiliki kualifikasi, kompetensi, dan sertifikasi sesuai dengan bidang tugasnya (Presiden Republik Indonesia, 2005).

\section{HASIL PENELITIAN DAN PEMBAHASAN}

\section{Pola Pengembangan Kompetensi Umum}

Pola pengembangan kompetensi umum tenaga kependidikan di Madrasah Ibtidaiyah di lingkup Kementerian Agama Kabupaten Kerinci yaitu dengan melalui pendidikan dan pelatihan (diklat), workshop, dan pembinaan lainnya. Pola pengembangan kompetensi umum tersebut cukup optimal diberikan kepada tenaga kependidikan di Madrasah Ibtidaiyah di lingkup Kementerian Agama Kabupaten Kerinci, namun pengembangan tersebut masih perlu ditingkatkan agar tenaga kependidikan dapat memahami tugas dan tanggung jawabnya serta memiliki produktivitas yang baik dalam bekerja.

\section{Pola Pengembangan Kompetensi Teknis/Fungsional}

Pola pengembangan kompetensi fungsional tenaga kependidikan di Madrasah Ibtidaiyah di lingkup Kementerian Agama Kabupaten Kerinci, yaitu dilakukan berdasarkan jabatan dari tenaga kependidikan tersebut, seperti pelatihan fungsional, pengembangan kompetensi IT, pelatihan struktural atau jabatan. Pola pengembangan kompetensi fungsional tersebut cukup optimal diberikan kepada tenaga kependidikan di Madrasah Ibtidaiyah di lingkup Kementerian Agama Kabupaten Kerinci, namun pengembangan tersebut masih perlu ditingkatkan agar tenaga kependidikan yang menempati jabatan tertentu yang tidak sesuai dengan latar belakang pendidikan yang mereka miliki mampu bekerja dengan optimal. 


\section{Pola Pengembangan Kompetensi Manajerial}

Pola pengembangan kompetensi manajerial tenaga kependidikan di Madrasah Ibtidaiyah di lingkup Kementerian Agama Kabupaten Kerinci dikembangkan berdasarkan jabatan agar mampu deduktif dalam mengelola apa yang menjadi tanggung jawabnya. Pola pengembangan kompetensi manajerial tersebut sudah cukup optimal siberikan kepada tenaga kependidikan di Madrasah Ibtidaiyah di lingkup Kementerian Agama Kabupaten Kerinci, namun masih perlu dikembangkan atau ditingkatkan agar tenaga kependidikan yang menduduki jabatan sebagai pemimpin/manajer pada bagian tertentu dapat mengerjakan pekerjaannya sesuai dengan tugas pokok organisasi.

\section{Faktor-faktor yang Memengaruhi Pengembangan Kompetensi}

Faktor internal di sini mencakup keseluruhan kehidupan organsiasi yang dapat dikendalikan baik oleh pimpinan maupun oleh anggota organisasi yang bersangkutan (Wibowo, 2009). Secara terinci faktor-faktor tersebut antara lain 1) visi, 2) misi, 3) tujuan, 4) strategi pencapaian tujuan, 5) sifat dan jenis kegiatan, dan 6) jenis teknologi yang digunakan. Terkait dengan data yang diperoleh di lokasi penelitian bahwa faktor-faktor internal seperti visi, misi, tujuan, strategi pencapaian tujuan, sifat dan jenis kegiatan, serta jenis teknologi yang yang digunakan sangat memengaruhi pengembangan kompetensi tenaga kependidikan di Madrasah Ibtidaiyah di lingkup Kementerian Agama Kabupaten Kerinci.

Adapun faktor-faktor eksternal yang dapat memengaruhi pengembangan kompetensi tenaga kependidikan menurut Fatmawada (2016) antara lain 1) Kebijakan pemerintah, 2) Sosio-budaya masyarakat, 3) Perkembangan ilmu pengetahuan dan teknologi. Terkait dengan data yang diperoleh di lokasi penelitian bahwa faktor-faktor eksternal seperti kebijakan pemerintah, sosiobudaya masyarakat, dan perkembangan ilmu pengetahuan dan teknologi sangat memengaruhi pengembangan kompetensi tenaga kependidikan di Madrasah Ibtidaiyah di lingkup Kementerian Agama Kabupaten Kerinci.

\section{SIMPULAN DAN SARAN}

Berdasarkan hasil penelitian mengenai pengembangan kompetensi tenaga kependidikan di Madrasah Ibtidaiyah dapat ditarik kesimpulan, yakni pola pengembangan kompetensi umum, fungsional, dan manajerial tenaga kependidikan di Madrasah Ibtidaiyah untuk saat ini telah sudah cukup optimal diberikan kepada tenaga kependidikan di Madrasah Ibtidaiyah di Kabupaten Kerinci. namun pelaksanaannya masih perlu ditingkatkan atau dikembangkan yang masih kurang atau belum optimal diberikan kepada tenaga kependidikan agar tenaga kependidikan tersebut dapat memiliki kinerja yang baik serta dapat memiliki efisiensi dan efektivitas dalam bekerja. Faktor-faktor yang memengaruhi pengembangan kompetensi tenaga kependidikan di Madrasah Ibtidaiyah di Kabupaten Kerinci adalah 1) faktor internal yang terdiri dari visi, misi, tujuan, strategi pencapaian tujuan, sifat dan jenis kegiatan, serta jenis teknologi yang digunakan. 2) Faktor eksternal yang terdiri dari kebijakan pemerintah, sosio-budaya masyarakat, perkembangan ilmu pengetauan dan teknologi.

\section{DAFTAR PUSTAKA}

Almasri, M. N. (2016). Manajemen Sumber Daya Manusia: Implementasi dalam Pendidikan Islam. Kutubkhanah: Jurnal Penelitian Sosial Keagamaan, 19(2), 133-151.

Azmy, A. (2015). Pengembangan Kompetensi Sumber Daya Manusia Untuk Mencapai Career Ready Profesional di Universitas Tanri Abeng. Binus Business Review, 6(2), 220-232.

Fatmawada s. (2016). Pengembangan Kompetensi tenaga Kependidikan di Universitas Negeri Makassar. Jurnal Office, 2(2), 109-114.

Hadiyanto, H. (2004). Mencari Sosok Desentralisasi Manajemen Pendidikan di Indonesia. Jakarta: Rineka Cipta.

Hasibuan, M. (2006). Manajemen Sumber 
Daya Manusia. Jakarta: Bumi Aksara.

Munirah, M. (2015). Sistem Pendidikan di Indonesia: Antara Keinginan dan Realita. Auladuna: Jurnal Pendidikan Dasar Islam, 2(2), 233-245. Retrieved from http://journal.uinalauddin.ac.id/index.php/auladuna/article/ download/879/849

Presiden Republik Indonesia. Undang-Undang Sistem Pendidikan Nasional, Pub. L. No. 20 (2003). Indonesia.

Presiden Republik Indonesia. Standar Nasional Pendidikan, Pub. L. No. 19 (2005). Indonesia.
Sedarmayanti. (2009). Sumber Daya Manusia dan Produktivitas Kerja. Bandung: Mandar Maju.

Wibowo. (2009). Manajemen Kinerja. Jakarta: Rajawali Pers.

Widodo, H. (2015). Potret Pendidikan di Indonesia dan Kesiapannya dalam Menghadapi Masyarakat Ekonomi Asia (MEA). Cendikia, 13(2), 293-307.

Zaini, A. (2016). Pengembangan Manajemen Sumber Daya Manusia Bagi Organisasi Dakwah. TADBIR, 1(1), 1-17. 